\title{
Is the mouse LD50 unit here to stay
}

\author{
Michael Adler
}

Neurotoxicology Branch, Analytical Toxicology Division,

US Army Medical Research Institute of Chemical Defense, 3100 Ricketts Point Road,

Aberdeen Proving Ground,

Maryland 21010-5400, USA

E-mail: michael.adler2@us.army.mil

\begin{abstract}
Investigators adopted the mouse LD50 unit for quantifying botulinum neurotoxin (BoNT) in the early 1900s, and through a combination of necessity and tradition, public health agencies, laboratory researchers, clinicians and manufacturers of BoNT have continued to use the mouse LD50 unit as the gold standard for expressing toxin quantity and potency. A recent article by Pickett (2011) questions whether there is still a need in the botulinum community to continue to use this bioassay and raises issues regarding a lack of standardisation in the reporting of toxin preparations.
\end{abstract}

Keywords: botulinum neurotoxin; BoNT; mouse lethality assay, LD50; neurotoxin-associated proteins; units; potency.

Reference to this paper should be made as follows: Adler, M. (2012) 'Is the mouse LD50 unit here to stay', The Botulinum J., Vol. 2, No. 2, pp.96-98.

Biographical notes: Michael Adler is a Research Pharmacologist at the US Army Medical Research Institute of Chemical Defense (USAMRICD), located at Aberdeen Proving Ground, Maryland. He received his $\mathrm{PhD}$ in Medical Pharmacology from the State University of New York at Buffalo and obtained his post-doctoral training at the National Institutes of Health at Bethesda, Maryland. His current research has focused on the development of small molecule and other therapeutics for botulinum neurotoxin and on the development of nerve agent pretreatments and therapies. He has published over 100 peer-reviewed papers and book chapters and holds several patents.

In a recent article in The Botulinum Journal entitled 'Units, weights and concentrations: the botulinum toxin dilemma', important issues were raised regarding the lack of standardisation in the expression of botulinum neurotoxin (BoNT) units in the literature, and the continued reliance on mouse lethality assay as a measure of BoNT potency (Pickett, 2011). Reliance on bioassays, especially those that use death as the endpoint, has declined in most fields, being supplanted by more precise analytical assays (Lee et al., 2010; Astashkina et al., 2012). However, the mouse bioassay continues to be used as the 'gold standard' by BoNT investigators and clinicians (Wilder-Kofie et al., 2011).

Historically, use of mouse lethality units (LD50) was necessitated by the fact that the molecular weight of the BoNT was not known with certainty until DasGupta and Borroff (1968) established that BoNT-producing bacteria secreted both a $150 \mathrm{kDa}$ toxic protein 
responsible for muscle paralysis and a group of non-toxic hemagglutinin proteins, which are now designated 'neurotoxin-associated proteins' (NAPs) (Fu et al., 1998). NAPs were demonstrated to bind non-covalently with the neurotoxin and served to protect it from degradation in the gastrointestinal tract (Sharma et al., 2003; Gu et al., 2012). For serotype A, the binding of NAPs with neurotoxin leads to formation of three different high molecular weight complexes: $300 \mathrm{kDa}, 500 \mathrm{kDa}$ and $900 \mathrm{kDa}$ (Chen et al., 1998; Sharma et al., 2003). Because NAPs are known to dissociate from the neurotoxin at neutral or alkaline $\mathrm{pH}$, the ratio of free to complexed neurotoxin depends on factors such as ionic strength and especially $\mathrm{pH}$ (Chen et al., 1998). Consequently, the state of aggregation of the toxin, and therefore the molecular weights of the different sized aggregates, cannot be inferred from knowledge of the starting material, but must be determined empirically (Eisele et al., 2011).

In many older studies, especially those performed prior to the 1960s, investigators often prepared their own toxin, and experiments were carried out with crude or partially pure toxin obtained from different clostridial strains. This led to variations in the potency of BoNT preparations not only among different laboratories but also with different batches of toxin from the same laboratory. Until pure neurotoxin became readily available, mouse LD50 units were the only practical means of standardising toxin potency.

An additional issue raised by Pickett's article is the omission of critical information on the preparation of BoNT by a large number of authors. Thus, an electrophysiological study conducted by Antony and Tonge (1980) described the use of BoNT to elicit chemical denervation of skeletal muscle, but failed to provide such essential information as the source of toxin or potency of the stock solution. In considering Pickett's arguments, two thoughts stand out. First, it is likely that the mouse LD50 will continue to be used to describe the potency of BoNT for the foreseeable future is spite of recent advances in vitro assays. Although new assays, especially those using stem cell-derived neurons, should be able to duplicate many of the features of the intact animal, the mouse LD50 assay is so deeply entrenched that many years of validation will be needed to engender sufficient confidence to abandon the dependable mouse (McNutt et al., 2011; Whitemarsh et al., 2012). Second, since BoNT is so highly selective in targeting cholinergic nerve terminals, the uncertainty of toxin source or concentration does not necessarily compromise the validity of the results but only obscures the quantitative aspects of the outcome. Fortunately, the ready access of pure neurotoxin should greatly reduce the uncertainties of toxin potency and purity in future studies.

\section{References}

Antony, M.T. and Tonge, D.A. (1980) 'Effect of denervation and botulinum toxin on muscle sensitivity to acetylcholine and acceptance of foreign innervations in the frog', Journal of Physiology, June, Vol. 303, No. 1, pp.23-31.

Astashkina, A., Mann, B. and Grainger, D.W. (2012) 'A critical evaluation of in vitro cell culture models for high-throughput drug screening and toxicity', Pharmacology Therapeutics, January 10 (epub ahead of print).

Chen, F., Kuziemko, G.M. and Stevens, R.C. (1998) 'Biophysical characterization of the stability of the 150-kilodalton botulinum toxin, the nontoxic component, and the 900-kilodalton botulinum toxin complex species', Infection and Immunity, Vol. 66, No. 6, pp.2420-2425. 
DasGupta, B.R. and Borroff, D.A. (1968) 'Separation of toxin and hemagglutinin from crystalline toxin of clostridium botulinum type A by anion exchange chromatography and determination of their dimensions by gel filtration', Journal of Biological Chemistry, March, Vol. 243, No. 5, pp.1065-1072.

Eisele, K.H., Fink, K., Vey, M. and Taylor, H.V. (2011) 'Studies on the dissociation of botulinum neurotoxin type A complexes', Toxicon, Vol. 57, No. 4, pp.555-565.

Fu, F-N., Sharma, S.K. and Singh, B.R. (1998) 'A protease-resistant novel hemagglutinin purified from type A Clostridium botulinum', J. Protein Chem., Vol. 17, No. 1, pp.53-60.

Gu, S., Rumpel, S., Zhou, J., Strotmeier, J., Bigalke, H., Perry, K., Shoemaker, C.B., Rummel, A. and Jin, R. (2012) 'Botulinum neurotoxin is shielded by NTNHA in an interlocked complex', Science, Vol. 335, No. 6071, pp.977-981.

Lee, M.Y., Dordick, J.S. and Clark, D.S. (2010) 'Metabolic enzyme microarray coupled with miniaturized cell-culture array technology for high-throughput toxicity screening', Methods in Molecular Biology, Vol. 632, pp.221-237.

McNutt, P., Celver, J., Hamilton, T. and Mesngon, M. (2011) 'Embryonic stem cell-derived neurons are a novel, highly sensitive tissue culture platform for botulinum research', Biochemical Biophysical Research Communication, April, Vol. 405, No. 1, pp.85-90.

Pickett, A. (2011) 'Unit, weights and concentrations: the botulinum toxin dilemma', The Botulinum Journal, Vol. 2, No. 1, pp.4-5.

Sharma, S.K., Ramzan, M.A. and Singh, B.R. (2003) 'Separation of the component of type A botulinum neurotoxin complex by electrophoresis', Toxicon, March, Vol. 41, No. 3, pp.321-331.

Whitemarsh, R., Strathman, M., Chase, L., Stankewicz, C., Tepp, W., Johnson, E. and Pellett, S. (2012) 'Novel application of human neurons derived from induced pluripotent stem cells for highly sensitive botulinum neurotoxin detection', Toxicol Sci., January 19, Vol. 126, No. 2, pp.426-435.

Wilder-Kofie, T.D., Lúquez, C., Adler, M., Dykes, J.K., Coleman, J.D. and Maslanka, S.E. (2011) 'An alternative in vivo method to refine the mouse bioassay for botulinum toxin detection', Comparative Medicine, June, Vol. 61, No. 3, pp.1-8. 